\title{
Design at the root of biophilia. Imitation. Nature
}

\author{
Dżoana Latała-Matysiak ${ }^{1}$, Marcin Marciniak $^{2}$ \\ ${ }^{1}$ Department of Geography and Landscape Design, Institute of Socio-Economic Geography \\ and Spatial Planning, Faculty of Economics, Opole University; \\ Ozimska St. 46a, 45-058 Opole; \\ dzoana.latala-matysiak@uni.opole.pl (ID)0000-0002-3817-6787 \\ ${ }^{2}$ Department of Intermedia, Institute of Visual Arts, Faculty of Art, Opole University; \\ Wrocławska St. 4, 46-020 Opole; \\ mmarciniak@uni.opole.pl (D)0000-0002-7295-4319
}

\begin{abstract}
According to the current state of research on the phenomenon of biophilia, the positive influence of nature's elements on humans has long been widely understood. Since the negative impact of urbanised areas on quality of life was noticed, human-friendly architecture has been redefined, where the physical and mental well-being of people using buildings, remains highly dependent on their contact with the environment. Selected examples of existing buildings analysed two different approaches to contemporary biophilic architecture; one where nature is the pedestal of the whole building and one where the interpretation of nature translates into technological, engineering or structural solutions. The architectural examples modelled on nature have gained recognition in local communities and worldwide renown, so it can be concluded that the flourishing of organic and bionic architecture is fully justified. Biophilia determines human well-being, while remaining closely related to the natural environment.
\end{abstract} nature

Keywords: organic architecture, contemporary architecture, landscape architecture, biophilia,

\section{Introduction}

To put it simply, biophilia can be defined as a consciousness-rooted love of nature. "Art imitates nature and supplements the ubiquitous (and discovered by the human) deficits" [4, p. 206]. Although the viewpoint on the inspiration by nature has evolved throughout the centuries, the imitation or negation of the inspiration by nature constituted a topic for discussion in every epoch. Thus, considering architecture is art, it is difficult not to notice floral ornaments in detail or the form of some buildings. When analysing the placement of the elements of the façade a golden ratio, which is commonplace in nature, can be spotted. "Architecture, not less than painting, has been an imitation of nature through the intuition of its basic rights. (...) The finest architecture is one that was close to nature" [13, p. 165]. However, as the most primary function of a building is shelter, 
it is very important to analyse its relationship with the surroundings. "It is commonly understood that the basic function of architecture is the protection of its user from the environmental conditions, which often "cuts out" the user from the outside world". It is equally important therefore, to ensure a harmonious existence of humans and nature [7, p. 45]. Current research of the biophilia phenomenon shows a positive influence of elements of nature on humans [8]. Human integration with nature is paramount, it positively influences mental focus and general wellbeing. "An architect also cooperates with living creatures - people, who are even more unpredictable than plants. If they won't feel well in the house that was built for them, the beauty of the building becomes useless, because the house voided of life becomes peculiar" [12, p. 14].

This article analyses two different approaches to biophilic architecture. The first one depicts nature as the pedestal of the whole building. The exposition of this principle resulted in the synthesis of the building with the surrounding landscape. The second viewpoint shows buildings mimicking nature, which on one hand are strikingly unnatural, and on the other expose the tour de force of technology and engineering of modern architecture. Architectonic examples where chosen specifically to depict natural elements - rocks and water - both in harmonic and artificial context. Such strong contrast enhances the two opposites of biophilic architecture, which were analysed and characterised in this article.

Rock caves have provided shelter to humans from the prehistoric times, therefore the use of this natural phenomenon as an example is an obvious choice. In addition, objects carved in stone were being created since the ancient times, in various parts of the world. They were mostly used as a place of worship, however some of them served as homes. The objects in question are complexes of man-made caves, which up to this day amaze with their sophistication and craftsmanship. Their value is attested by the fact that they belong to the World Heritage List, UNESCO. Especially worth mentioning are the ruins of the Nabatean town in Petra in Jordan, Mesa Verde National Park in the United States, the valley of Bâmyân river in Afghanistan, or Turkish Cappadocia.

The second natural component analysed in this paper is water, an element essential for life. Human settlement has always been constrained by the location of rivers and sweet water reservoirs. The element of water has been a subject of worship for many civilisations, and its healing powers have been recognised since the ancient times until present. Moreover, the impressive development of balneological parks proves that despite the evolution of hydro technology, the proximity of natural water sources is still deemed essential.

These two elements: water and rocks - in terms of architecture - have contributed most to human survival.

\section{Biophilia in architecture}

Since the ancient times, archetypal examples of nature have been duplicated on facades of buildings as ornaments and details. Such aesthetics, in addition to its symbolism, did not convey the idea of biophilia and longing for nature. It was not until the $19^{\text {th }}$ century when abrupt changes took place in the industry and technology, which resulted in sterilisation of buildings and spaces adjacent to them. The degradation of biodiversity, green spaces, namely the creation of heat islands, resulted in the loss of the contact between humans and nature. The fact that urbanised areas have a negative influence on the quality of life was noted and at the same time first definitions of human-friendly architecture were coined. "It would be wrong to say that space and surroundings have no effect on behaviour and feelings of their users" [9, p. 29]. Physical and mental wellbeing of humans is highly dependent on their contact with the natural environment. "At the source of all theories and hypotheses related to mechanisms of perception and preference is so-called biophilia hypothesis, 
which assumes that the general tendency to natural environments preference is an outcome of the 'genetic code' created throughout millions of years of humans inhibiting the earth" [1, p. 28]. Therefore, the efforts were begun to restore what was taken away from humans as a result of industrial revolution and industrialisation of space. It seems obvious that "crucial biophilic needs are related to the desire of health, efficiency, and wellbeing" [8, p. 183] and that these values are the negation of the modern metropolitan environment. Excessive surface sealing and heavy pollution of air and water resulted not only in negative changes in the local environment, but also in the climate change. The development of civilisation diseases caused by the reception of negative stimuli had an effect both on physical and mental health of the society." recipients consider natural landscapes to be particularly attractive, albeit with signs of management, with a high degree of diversity in spatial elements and species, and with a moderate or high degree of complexity". These preferences condition the necessity of a balanced development. A designed landscape should be managed in a way that would prevent further degradation and negative transformation of space, assuring a captivating visual layer at the same time. It is important to mention that Kellert defined biophilia as a biologically 'weak' feature, thus it can be hidden or can disappear completely as a result of the neglect of simulation and maintenance of biophilic values [3, p. 3]. The author of the thesis in chapter one of 'Dimensions, Elements, and Attributes of Biophilic Design' focused on singling out features that have a positive influence on the psyche of users. He identified two fundamental dimensions of the biophilic project - organic or naturalistic and a dimension based on locality or tradition. Additionally, he distinguished six elements of the biophilic project: environmental functions, natural shapes and forms, natural templates and designs, light and space, relations based on locality, and development of human-nature relations. These elements are combined with seventy attributes, which together constitutes detailed tips for designers and developers, with an aim of creating constructions of positive influence of the users' psyche. In this publication authors compared the above features, dimensions, components, and attributes, which they assigned to the analysed buildings in relation to various forms of imitating nature. The theories of Wilson and Appleton showed that even a simple contact with a replica of a flower or a pattern that occurs in nature has a positive effect on retaining good spirits [14, p. 952]. The imitation of nature was defined anew as one of the elements of biophilic design.

\section{Harmony - a synthesis of nature and landscape}

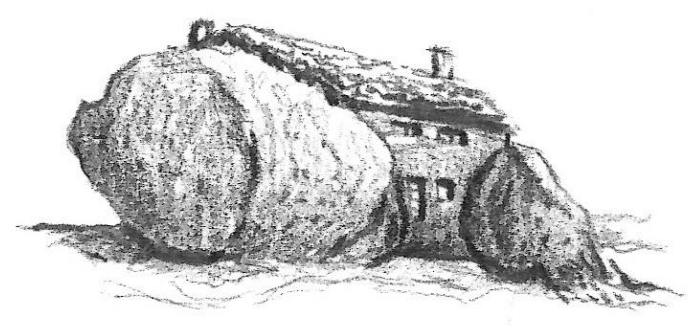

Fig. 1. Casa do Penedo

(Dżoana Latała-Matysiak, sketch, 2020)

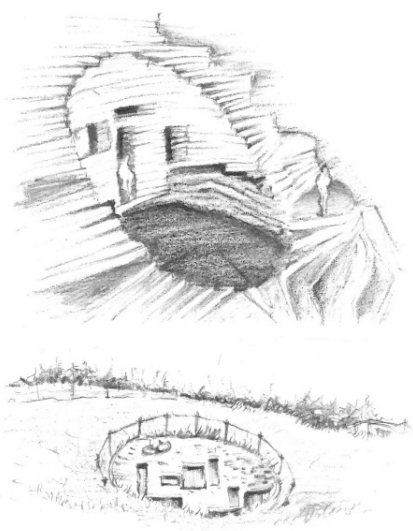

Fig. 2. Villa Vals, proj. SeARCH \& CMA(Dżoana Latała-Matysiak, sketch, 2020) 


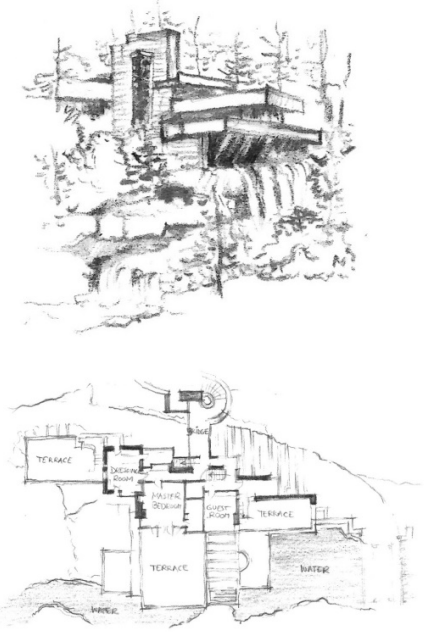

Fig. 3. Fallingwater, proj. Frank Lloyd Wright (Dżoana Latała-Matysiak, sketch, 2020)
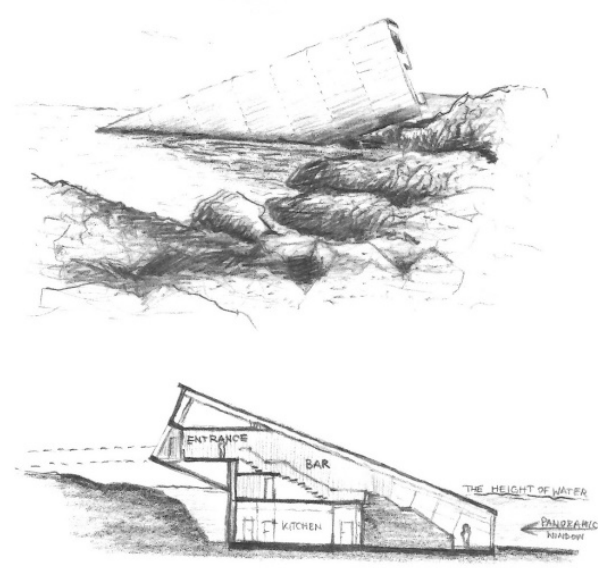

Fig. 4. Under, proj. Snøhetta

(Dżoana Latała-Matysiak, sketch, 2020)

The agreement of structures, colours, and shapes, and a consequent use of natural materials sourced from local fields is the first action that comes to mind when considering the integration of man-made and natural elements. A significant example of such action is Casa do Penedo (Fig. 1), known also as Stone House. A small house is located in northern Portugal about $14 \mathrm{~km}$ from a town Fafe, in Braga district. A foundation of its structure are four massive boulders guiding the outline, height as well as width of the building. The house is almost entirely built of stone, with an exception of small windows, doors, and roofing. The man-made elements were made of materials, the look of which does not negatively influence the visual impression of naturality. The building is an excellent example of the integration of architecture with the surrounding landscape. When looked at from the distance, it seems to be camouflaged among surrounding rocks. At closer exploration the house seems to be squeezed or tucked in between the rocks, thanks to a distorted statics of window openings. It is hard to resist the impression that the building wants to be as close as possible to nature. This impression is amplified by the fact that despite the proximity of the wind power plant, there is no electricity in the house. The building is so unique that it caught the interest of the main information portals [23], [26], [27], and the house became an icon, one of the most grotesque and at the same the most picturesque buildings in the world.

The second project, which was created with the same intention and with the complete integration of the building into the landscape, is Villa Vals (Fig. 2) located in Switzerland. The contemporary building, completed in 2009 by the architects of the SeARCH \& CMA group, redefines the integration of architecture with the natural environment. The Villa gives the impression of "camouflaged", embedded in a mountain slope. The usable space is located underground, only the central patio "cutting" into the steep slope creates a big facade with a large area of window openings [35]. Due to the lack of extraordinary cubature, the Villa is visible only at the top of the mountain, or from the slopes on the opposite side - it does not interfere with the landscape. 
Casa do Penedo and Villa Vals falls within the definition of the first fundamental dimension of Kellert's biophilic design, where architecture has naturalistic or organic features, defined as a shape in the visual sphere [3, p. 5]. Thus, it comes naturally to refer to the 1939 Fallingwater project by Frank Lloyd Wright (Fig. 3), who introduced the notion of biophilia to the general terminology. This architect defined the concept in an interview he gave to NBC television in 1958. "The meaning of organic, in philosophical sense, is being. Organic means, in a philosophical sense, being. Where the whole applies to parts and parts apply to the whole. Where the nature of materials, the nature of the purpose, the nature of the whole performance become a necessity, it follows what significance can be given to the building as a creator" [22]. Wright's life's work was based on the relation among the building, human, and nature. This relation was classified as a special value and the connection between a building and landscape as key elements of development of the modern architectural design of the $20^{\text {th }}$ century [29]. In celebration of these values Fallingwater was included in the World Heritage List, UNESCO [29] in 2019, as one of eight buildings designed by Wright.

The connection between the building and landscape, places the building in the second fundamental area of Kellert's biophilic design. Said dimension is based on localisation, which is in turn linked to culture and identity, and the ecology of the place or geographical region [3, p. 6]. It encompasses site-specific as well as genius loci. Fallingwater is located in Mill Run, Pennsylvania, in Bear Run Natural Reserve. The waterfall, above which the building was erected, was a starting point of the whole project, constituted a part of the entirety, and at the same time the part was the whole. In his own words "It is a part of its environment and serves more as an ornament than a disgrace" [28]. This synthesis does not only lead to harmony in the visual layer, but also provides a new definition of domestic tranquillity. "Fallingwater is a great blessing, one of great blessings, which can be experienced on earth, I think there is nothing that equalled to coordination, the feeling of solidarity, where the forest and stream, rocks, and all structural elements are conjoined in such subtle manner that truthfully no noise is audible, even though the sound of falling water can be noticed" [11, p. 53].

The bond of the building with the natural environment is clearly visible in the contemporary realization "Under” (Fig. 4), completed in 2019. An underwater restaurant designed by the Snøhetta office is located off the coast of the village of Båly in Norway. The 34-meter-long monolithic body of the building rests directly on the seabed, 5 meters below the surface of the water. The contemporary form in no way imitates the surrounding landscape. "The structure has been designed to fully integrate into the marine environment over time as the roughness of the concrete shell will function like an artificial reef" [31].

The harmony and spatial manipulation between architectonic and natural environments, a skilful fusion of light, mass, and ratio favours the feeling of comfort and moving in various conditions [3, p. 11]. This is how the fourth biophilic element, which can be easily noticed in both the Fallingwater and Under projects, was defined. What's interesting, in the first case, building the layout of rooms was designed so that the user experienced the tightness and felt claustrophobic in dark and narrow corridors located on the outside of the house. The further from the centre, the more open the space becomes to finally integrate into the landscape. In the Under building, the panoramic window allows the restaurant's customers to observe nature. "For most of us, this is a whole new world experience. This is not an aquarium, these are wild animals of the North Sea. This 
makes it much more interesting. It leads directly to the wild." - Rune Grasdal, Principal Architect of Under [26].

\section{Disharmony - the proximity to nature through imitation}

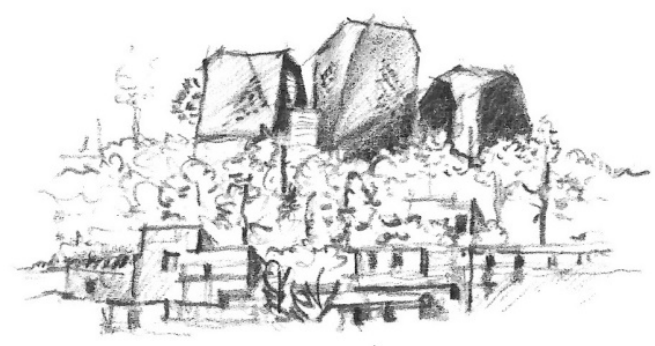

Fig. 5. Biblioteca España, proj. Giancarlo Mazzanti (Dżoana Latała-Matysiak, sketch, 2020)

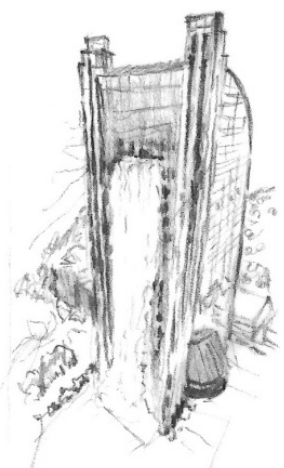

Fig. 7. Liebian International Plaza, proj. Cheng Xiamao (Dżoana Latała-Matysiak, sketch, 2020)

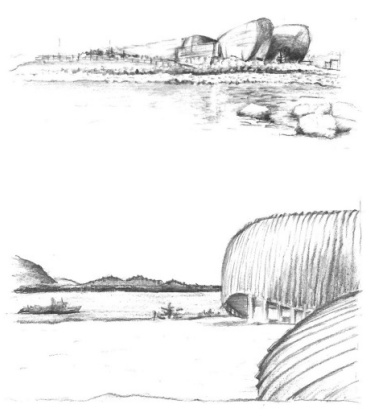

Fig. 6. Centro Eventi Multifunzionale, proj. Bargone Architetti Associati (Dżoana Latała-Matysiak, sketch, 2020)

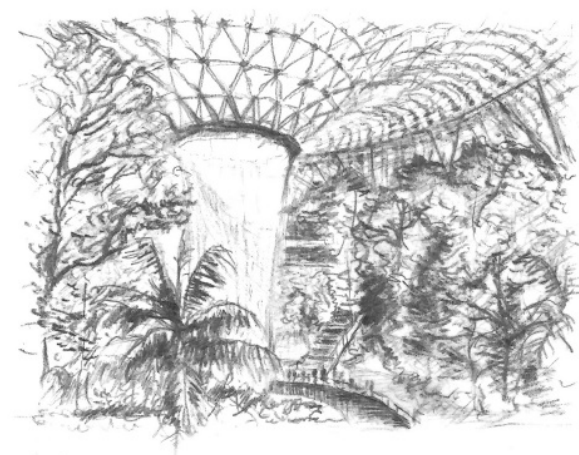

Fig. 8. Jewel Changi Airport - Rain Vortex, proj. WET Design (Dżoana Latała-Matysiak, sketch, 2020)

"The problem of falseness and imitation has been present in architecture actually since the beginning of time" [10, p. 162]. This trend has been enhanced due to the notion of eclecticism, which has been unwittingly imitating the architecture of previous eras. It is the $19^{\text {th }}$ century that is often described as "the most imitated and false century in the history of architecture" [10, p. 154]. Imitation continues at its best, mainly thanks to bionic and organic forms, which are modelled on nature. Biblioteca España (Fig. 5), completed in 2007, which towers over the city of Medellín in Colombia, was created in such spirit. The complex comprises three blocks, styled to resemble massive boulders, which due to their placement are perfectly exhibited in almost all parts of the city.

ArchDaily created a perfect definition of this architecture: "a landscape building that redefines the folded mountainous structure in form and space, nullifying the idea of landscape 
like a background and encouraging the ambiguity building - landscape" [21]. This pioneering approach to site-specific architecture makes the building not only want to integrate with the landscape, but also becomes its interpretation. This can be assigned to the second biophilic element of this project - natural forms and shapes. One of the developments of this point is the metaphoric representation of landscape, which appears integrated [3, p. 9]. According to Kellert artificiality, although imitation of nature is popular, it rarely causes a lasting positive response, even if it is an exact copy. The progress of natural vanishing evokes the feeling of closeness and satisfaction, and this process takes place incomparably slower when durable material is used. In case of Biblioteca España, the façade of the building is cladded with natural stone to make it resemble the rocks. Importantly, a pronounced division of panels is visible, and the form of individual rocks is geometrical, sharp, and modern. Architecture never pretends to be something it is not. Inspiration by nature is visible in form, however thanks to the building's dynamic shape we can recognise the artificial element in the landscape.

We can draw the same conclusions when looking at the Centro Eventi Multifunzionale [CEM] (Fig. 6) project located in the Italian town of Verbania. The complex, completed in 2016, grows out of a unique union of mountains, city and water. Here, too, the facade made of sheet metal with a clear joint does not imitate the perfectly oval structure, and its colour harmonizes with both the lake and the sky. "The lake stone is the symbol of the project and the striking context of the surroundings was the centre's greatest challenge," said Bargone Associati, co-founder Federico Bargone [25]. Although the location and the perspective of viewing both complexes - Biblioteca España and Centro Eventi are significantly different, both forms have many common features. With reference to "landscape architecture". The complex integrates with the surroundings, and the boundary between the architectural form and the landscape is graded by incorporating a natural amphitheatre, where descending concrete stands allow users to observe a breath-taking view of the lake and the surrounding Alps.

Surface buildings designed by Frank Lloyd Wright - Fallingwater and Giancarlo Mazzanti - Biblioteca España differ, however when we compare the notion of organic architecture defined by Wright with Mazzanti's idea of architecture, we notice that the building-human-nature relationship is paramount in work of both architects. The website of EQUIPPO MAZZANTI, a design studio established by Mazzanti, reads that the team "believes architecture is one of the keys for the construction of a more competitive and sustainable society. The studio reaches out to contribute towards social transformation and wellbeing, devising detailed contextual research, and involving local actors through its design process" [25].

Frank Lloyd Wright spoke negatively about imitation, in his words "architecture will transform into fraud" [18, p. 171]. Le Corbusier summarised this phenomenon using slightly less forceful language: "sculpture and painting appear in architecture then, when a mistake needs to be concealed" [20, p. 10]. Therefore, it can be concluded that main impulses that conditioned imitation were economic conditions and technological shortcomings. However, when looking at the Liebian International Plaza complex (Fig. 7) in China, it is hard to repel the impression that in this case, it was the engineering and technological craft that was the motivation to the creation of the highest artificial waterfall located in a built-up area. Interestingly, the purchase of technology is the sixth, and last, biophilic element, according to Kellert. It is classified as an intrigue, temptation, the need of exploration, discoveries, secrets, and creativity related to problem-solving. These features are the synthesis of intellect and imagination, which has a positive effect on the human-nature relationship [3, p. 13]. "Architecture is an art inseparably linked to technology" [6, p. 187], and the level of design is a derivative of many factors, but mainly cultural and socio-economic factors [19, p. 102]. This explains the seed 
of insanity in the project, which was built in a country that has one of the largest economies of the world.

The Liebian International Plaza is not trying in any way to pretend that it is a part of nature, but its shimmering, glass façade and dimension typical for skyscrapers do not weaken the biophilic influence. What is interesting, even with such artificial form, this building can be written into the Kellert's classification, into the first, alternative dimension of design, to be more specific: "Symbolic or substitute experience includes not real contact with real nature, but rather a representation of the world of nature through image, video, metaphor, and more" $[3$, p. 6].

Director of Ludi International Group and the skyscraper's designer, Cheng Xiamao, admitted that he wanted to link the construction with its location. Guiyang is located in the mountains and is so densely foliaged that it resembles a forest. What is interesting, Guiyang province is known for the largest waterfall in China, located in Huangguoshu National Park, with the largest in the world agglomeration of waterfalls [24]. Therefore, it is not surprising that the tallest, measuring 180 meters, artificial waterfall in an urban landscape was created in the capital of this Chinese province.

The second architectural record belongs to the 40m high Rain Vortex waterfall (Fig. 8), which is the main attraction of Jewel Changi Airport. It is the world's tallest indoor waterfall and its concept reflects Singapore's reputation as the "Garden City". The concept was realized by Safdie Architects and Peter Walker \& Partners, responsible for the selection of plants and landscape [23]. The waterfall itself was designed by the design company WET Design. The whole assumption, completed in 2019, is the art of technology whose heart is the waterfall. It is powered during violent storms, when water flowing from the roof of more than 10,000 gallons per minute can collect a significant amount of rainwater for reuse [30]. Water from the tanks is also used for passive cooling, as the recirculated rainwater disperses throughout the interior and flows down the entire glass façade.

Jewel Changi Airport can be classified on a par with Liebian International Plaza in terms of nature-inspired form and technology, and also embedded in the first, alternative dimension of design. In the case of the first assumption, however, the biophilic sensations are reinforced by lush vegetation, which is an almost faithful imitation of the forest. The nature of plantings carried out in accordance with the naturalization of the landscape enhances the feeling of communing with the real nature, so the biophilic feeling is multilevel.

\section{Conclusions}

A synthesis of two such different elements - artificial and natural - on its surface may seem to be only possible when imitation and assimilation of the visual layer of both elements is used. An adequate choice of rough texture, neutral colours, and rawness of form is the key here. However, while analysing a modern interpretation of architecture and nature, it can be found that they are nearly identical. "Nature, thanks to the use of biotechnology or the discovery of genetics, is designed and can be considered as one of the fields of design" [5, p. 31]. Architecture, on the other hand, due to the use of design programs, is defined with the use of parameters. "This in turn opens the way to understanding of architecture as a code and comparing it to DNA, the carrier of genetic information" [5, p. 7]. The above definitions of nature and architecture marked the beginning of the new branch of bionic architecture, where solutions observed in nature are being introduced. This concept does not always have the characteristics of biophilia, and the interpretation of nature translates into technological 
solutions. Nevertheless, the link between architecture, nature and technology is inseparable and its evolution continues today.

Casa do Penedo and Fallingwater are a negation of the era in which they were created. The $20^{\text {th }}$ century was focused on mass-production - uniqueness was in low demand, and it could only be materialized in a specific area or place. These objects were perfectly summed up by a Japanese architect - Kengo Kuma - "in this sense, I doubt if there is anything that has more character than architecture" [17, p. 8]. It was the desire of authenticity in the unauthentic times that lead to the creation of a new branch of architecture, where objects inspired by nature dominate modern design [7, p. 44].

Frank Lloyd Wright's words even though uttered a few decades ago, for many are still a marker of decent architecture. "Human homes should not look like blocks glistening in the sun. Every building erected to achieve people's goals should be like an element, like a thing coming from the earth, harmonizing with its natural surroundings and related to the area on which it stands. The house is not going anywhere" [18, p. 196]. Although the shape of Biblioteca Espana, Centro Eventi Multifunzionale or Under can be compared to building blocks, surely its integration with landscape and the clarity of its modern form, which is not blindly imitating the rocks, ideally reflects Wright's theory.

"The integration of art and proper technique has made old utopias achievable" [2, p. 73]. Requirements that modern architecture has with regards to the place and function that the building should have in the urban tissue caused that the construction sometimes shocked with its form. "Although beauty and originality are not mutually exclusive, originality often does not evoke beauty" [16, p. 438]. It is worth therefore to use examples, which we subconsciously regard beautiful. The golden ratio, which is a commonplace in nature, and which has been used in architecture for centuries, gives the recipient the impression of order and agreement. Thus, again, it is important to accept the superiority of nature as a prototype for imitation because "harmony (...) has been present in nature before people introduced it to art - nature aims to make all its works perfect, and this could not be possible without harmony" [15, p. 107].

Biophilia is recognized as an innate feature, which influences both mental and physical wellbeing of humans, highly dependent on contact with the natural environment. Abovementioned examples of nature-inspired architecture gained both recognition among local communities and as well as international acclaim, which is a result of the positive admiration of architecture described in this article. "Aesthetic attraction to nature is one of the strongest tendencies of the human species" [3, p. 14], and thus the blossoming of organic and bionic architecture can be fully justified.

\section{References}

[1] Błaszczyk M., "Kultura czy natura? Mechanizmy percepcji i preferencji wobec krajobrazu i form roślinnych”, Prace Komisji Krajobrazu Kulturowego, no. 36/2017, p. 21-32.

[2] Dobesz J., Wzajemne relacje sztuki, techniki, architektury i urbanistyki, in Integracja sztuki i techniki, Flizikowski J. ed., Wydawnictwa Uczelniane Uniwersytetu Technologiczno-Przyrodniczego, Bydgoszcz 2014.

[3] Kellert S.R., "Dimensions, Elements, and Attributes of Biophilic Design”, in Biophilic Design: the Theory, Science and Practice of Bringing Buildings to Life. John Wiley \& Sons, Hoboken, 2008, p. 3 - 19.

[4] Kiereś H., "Klasyczna teoria sztuki”, in U źródet tożsamości kultury europejskiej. Rakowski T. ed., Lubelska Szkoła Filozofii Chrześcijańskiej, Lublin, 1994, p. 201-218. 
[5] Klein L., Żywe architektury: analogia biologiczna w architekturze końca XX wieku. Fundacja Kultura Miejsca, Warszawa, 2004.

[6] Kurkowska A., "Integracja sztuki i techniki w kontekście przekazywania nastroju poprzez obiekt architektoniczny" in: Integracja sztuki i techniki w architekturze i urbanistyce, Flizikowski J. ed., Wydawnictwa Uczelniane Uniwersytetu Technologiczno-Przyrodniczego, Bydgoszcz, 2014, p. 185 $-196$.

[7] Maciejko A., "Inspiracje w architekturze. Część 2. Natura”, Builder Science, no. 06/2016, p. 44-47.

[8] Modrzewski B., Szkołut A., "Biofilia - teoria i praktyka projektowa", in BIOCITY. Górski F., Łaskarzewska-Średzińska M. ed., Wydział Architektury Politechniki Warszawskiej, Warszawa, 2014, p. $181-188$.

[9] Modrzewski B., Szkołut A., "Biofilia - człowiek w przestrzeni - przestrzeń wokół człowieka”, in Architektura a rozwój człowieka: ujęcie multidyscyplinarne. Kalus A., Mazurek E., Szymańska J. ed., Wydawnictwo Politechniki Wrocławskiej, Wrocław, 2015, p. 29 - 40.

[10] Niebrzydowski W., "Imitacje w architekturze", Teka Kom. Arch. Urb. Stud. Krajobr. - OL PAN, No. 2008B, p. $150-163$.

[11] Pfeiffer B.B., Frank Lloyd Wright 1867-1959 Building for Democracy. Taschen, Koln, 2004.

[12] Rasmussen S.E., Odczuwanie architektury. Wydawnictwo Karakter, Kraków, 2015.

[13] Rostański K.M., Natura modelowana. Elementy naturalistyczne w kompozycji urbanistycznej. Monografia. Wydawnictwo Politechniki Śląskiej, Gliwice, 2012.

[14] Söderlund J., Newman P., "Biophilic architecture: a review of the rationale and outcomes", AIMS Environmental Science, No. 2(4)/2015, p. 950 - 969.

[15] Tatarkiewicz W., Historia estetyki, tom II. Wydawnictwo Naukowe PWN, Warszawa, 2009.

[16] Tokajuk A., "Piękno, oryginalność, kicz i estetyka drugiej kategorii w architekturze współczesnej". Czasopismo Techniczne. Architektura, No. 13/6-A/2007, p. 438 - 442.

[17] Urbańska M.A., "Najnowsza Polska architektura site-specific: konserwacja tożsamości”, Czasopismo Techniczne. Architektura, No. 9/6-A/2015, p. 233-249.

[18] Wright F.L., Architektura nowoczesna: wyktady. Wydawnictwo Karakter, Kraków, 2016.

[19] Wybieralski W., Elementy wzornictwa w projektowaniu technicznym. Politechnika Warszawska, Warszawa, 2012.

[20] Żórawski J., O budowie formy architektonicznej, short shot edited by Lisowski B.; Lenartowicz J. K. ed., Politechnika Krakowska, Kraków, 2017.

[21] España Library, “Giancarlo Mazzanti”, ArchDaily, 17 Jun 2008. Available: https://www.archdaily. com/2565/espana-library-giancarlo-mazzanti [Accessed: 7 Oct 2020]

[22] Buckley S., "Frank Lloyd Wright Upholds Egotist Reputation in Interview", ArchDaily, 09 Oct 2017. Available: https://www.archdaily.com/881027/frank-lloyd-wright-upholds-egotist-reputation-in-interview [Accessed: 7 Oct 2020]

[23] Hilburg J., "Safdie Architects completes world's largest indoor waterfall", The Architect's Newspaper. Available: https://www.archpaper.com/2019/04/safdie-architects-jewel-changi-airport/ [Accessed: 7 Oct 2020]

[24] Kitching C., "Casa do Penedo", Daily Mail, 22 Nov 2015. Available: https://www.dailymail.co.uk/ travel/travel_news/article-3329206/Casa-Penedo-Flintstones-house-lures-tourists-Portugal-s-Fa. html [Accessed: 7 Oct 2020]

[25] Mairs J., "Lakeside theatre designed by Bargone Associati to look like huge rocks", Dezeen, 9 May 2016. Available: https://www.dezeen.com/2016/05/09/centro-eventi-multifunzionale-verbania-cultural-centre-bargone-architetti-associati-lake-maggiore-italy/ [Accessed: 7 Oct 2020] 
[26] Crook L., "Snøhetta completes Europe's first underwater restaurant in Norway”, Dezeen, 20 March 2019. Available: https://www.dezeen.com/2019/03/20/underwater-restaurant-under-snohetta-baly-norway/ [Accessed: 7 Oct 2020]

[27] Liebian International Plaza, "Cheng Xiamao", CNN Travel, 26 ${ }^{\text {th }}$ July 2018. Available: https://edition. cnn.com/travel/article/waterfall-skyscraper-china-guizhou/index.html [Accessed: 7 Oct 2020]

[28] Mazzanti G., EL EQUIPO MAZZANTI design office, official web site. Available: https://www. elequipomazzanti.com/en/about-us/ [Accessed: 7 Oct 2020]

[29] Forbes, Casa do Penedo. Available: https://www.forbes.com/pictures/ekkf45kd/casa-do-penedofafe-mountains-portugal/\#7ee74c17e31c [Accessed: 7 Oct 2020]

[30] Jewel Changi Airport, Safdie Architects. 2008. Available: https://www.safdiearchitects.com/ projects/jewel-changi-airport [Accessed: 7 Oct 2020]

[31] Snøhetta design office, Under, official website, 2019. Available: https://snohetta.com/project/428-under-europes-first-underwater-restaurant [Accessed: 7 Oct 2020]

[32] The Telegraph, Casa do Penedo, 11 Apr 2019. Available: https://www.telegraph.co.uk/travel/galleries/ unusual-remote-buildings-photographers-love/casa-do-penedo--portugal/ [Accessed: 7 Oct 2020]

[33] Hugh Down's interview with Frank Lloyd Wright, in The Master Architect: Conversations with Frank Lloyd Wright, Meehan P.J. ed., Wiley-Interscience, 1984. Available: https://www.theguardian. com/artanddesign/2007/oct/19/architecture4 [Accessed: 7 Oct 2020]

[34] Fallingwater, Frank Lloyd Wright. 07 Jul 2019. Available: https://whc.unesco.org/en/ list/1496 [Accessed: 7 Oct 2020]

[35] SeARCH \& CMA, "Villa Vals", Official website of the Villa Vals. Available: http://www.villavals. ch/design_architecture.php [Accessed: 7 Oct 2020] 
